\title{
Environmental benefits of genetically modified crops: Global and European perspectives on their ability to reduce pesticide use
}

\author{
R.H. Phipps and J.R. Park
}

\author{
Centre for Dairy Research, Department of Agriculture, \\ The University of Reading \\ Reading RG6 6AT, UK
}

(Received 27 November 2001; accepted 31 January 2002)

\section{ABSTRACT}

The Green Revolution, which brought together improved varieties, increased use of fertilizer, irrigation and synthetic pesticides, is credited with helping to feed the current global population of 6 billion. While this paper recognizes the ability of pesticides to reduce crop losses, it also discusses their potential negative effects on public health, with particular emphasis in developing countries, and the environment. The response of the agricultural industry in bringing forward new technology such as reduced application rates of targeted pesticides with lower toxicity and persistency is noted. However, with increasing world population, a slowing of the rate of crop improvement through conventional breeding and a declining area of land available for food production there is a need for new technologies to produce more food of improved nutritional value in an environmentally acceptable and sustainable manner. Whilst the authors recognize that the introduction of genetically modified (GM) crops is controversial, the benefits of these crops, including their effect on pesticide use is only now beginning to be documented. Published data are used to estimate what effect GM crops have had on pesticide use first on a global basis, and then to predict what effect they would have if widely grown in the European Union (EU). On a global basis GM technology has reduced pesticide use, with the size of the reduction varying between crops and the introduced trait. It is estimated that the use of GM soyabean, oil seed rape, cotton and maize varieties modified for herbicide tolerance and insect protected GM varieties of cotton reduced pesticide use by a total of 22.3 million $\mathrm{kg}$ of formulated product in the year 2000 . Estimates indicate that if $50 \%$ of the maize, oil seed rape, sugar beet, and cotton grown in the EU were GM varieties, pesticide used in the EU/annum would decrease by 14.5 million $\mathrm{kg}$ of formulated product ( 4.4 million $\mathrm{kg}$ active ingredient). In addition there would be a reduction of 7.5 million ha sprayed which would save 20.5 million litres of diesel and result in a reduction of approximately $73,000 \mathrm{t}$ of carbon dioxide being released into the atmosphere. The paper also points to areas where GM technology may make further marked reductions in global pesticide use.

KEY WORDS: GM crops, pesticide reduction, global, European Union 


\section{AN HISTORICAL PERSPECTIVE}

The Green Revolution, fathered in the 1960's by Norman Borlaug, heralded one of the major agricultural developments of the last century. The production of new cereal varieties, coupled with increased use of fertilizers, irrigation and pesticides, provided many of the technological inputs required to feed an expanding world population.

Since their introduction in 1947 , synthetic pesticides have been widely used to reduce crop losses due to insects, diseases and weeds. Even so these losses for eight of the world's major crops are estimated at US $\$ 244$ billion/annum, representing $43 \%$ of world production (Oerke et al., 1995) and post-harvest losses contribute a further $10 \%$. Paoletti and Pimentel (2000) estimated that, if it were not for synthetic pesticide use, current crop losses might well increase by a further $30 \%$. Huang et al. (2001) quote officials as saying that pesticide use saves China millions of tonnes of food and fibre every year.

Thus, the combined effects of improved varieties, increased fertilizer use and irrigation coupled with increased pesticide use has been instrumental in allowing world food production to double in the last 35 years (Tillman, 1999). Nevertheless, pesticides have been associated with a number of negative events that were unforeseen at the time of their adoption.

\section{SOME CONCERNS ASSOCIATED WITH CONVENTIONAL CROP PRODUCTION PRACTICES}

\section{Effects of pesticide use on public health}

In the 1970's the World Health Organisation (WHO) estimated that there were globally 500,000-pesticide poisonings/year, resulting in 5,000 deaths (Farah, 1994). However, Yudelman et al. (1998) considers that figures relating to pesticide poisoning should be treated with caution and note that the WHO is still trying to ensure accurate data collection.

The Environmental Protection Agency (EPA) estimates that between 10,000 and 20,000 cases of pesticide poisoning occur in agricultural workers each year in the USA. The problem of pesticide toxicity may be worse in developing countries due to less education on and lack of awareness of the inherent dangers of pesticides, inadequate protective clothing and lack of appropriate training. This is demonstrated by studies with women on smallholder cotton farms in Southern Africa (Rother, 2000). He noted that while the women appreciated that pesticides were poisons and had to be kept under lock and key, they were seen mixing pesticides and water with bare hands and that the mixture spilled out of the container and ran 
into water courses which were the water supply for the house. Women also collected edible weeds and grew vegetables for domestic use amongst the cotton. In earlier field studies with rice growers in the Philippines over half the farmers claimed sickness due to pesticide use (Rola and Pingali, 1993). These examples and others (Repetto and Baliga, 1996) show the inherent risks to pesticide users, particularly in developing countries.

\section{Environmental effects of pesticide use}

When synthetic pesticides were first introduced in the mid 1940's regulatory procedures providing approval for their use were limited. In the late 1960's Rachel Carson in her controversial book Silent Spring expressed the view that the increasing use of synthetic pesticides would have a serious negative effect on the environment. In the intervening years a number of examples have been documented which supported her original hypothesis. For example the Royal Society for the Protection of Birds has linked the dramatic decline in UK Farmland bird life to a number of factors such as the intensification of agriculture which includes increased pesticide use (Krebs et al., 1999). Paoletti and Pimental (2000) cite numerous examples of well-documented cases where pesticide application has been directly responsible for specific incidents in which large numbers of birds have been killed. The EPA (1982) has estimated that Carbofuron kills 1-2 million birds/year and Paoletti and Pimental (2000) have argued that based on a conservative estimate of $10 \%$ mortality, close to 70 million birds are killed annually in the USA as a direct effect of pesticide use.

However, it should be noted that in recent years the introduction of stricter legislation and new technology such as reduced application rates of targeted pesticides of lower toxicity and persistency, buffer zones and low drift technology are precautions now taken to try to decrease potential negative environmental effects of agrochemical use.

\section{Do we need new technology?}

As we move into the $21^{\text {st }}$ Century and world population increases towards 9 billion, cereal grain production will need to increase by one billion tonnes (Borlaug, 2001). Against a background of a static or declining area of land available for crop and livestock production and a decreasing rate of crop improvement through conventional breeding, there is a need for new technology to increase crop yield, improve nutritional quality of food and reduce crop losses. Societal pressure suggests this will need to be achieved in a manner ensuring safety for the public and the environment. Tillman (1999) noted that this major challenge to decrease the environmental impact of agriculture while maintaining or improving its productivity and 
sustainability would have no single easy solution. Genetically modified (GM) crops have been discussed as one of the possible ways forward with the aim of combining higher yields, improved food and feed quality with environmentally friendly agronomic practices (Phipps and Beever, 2000).

While the authors recognise that there are many controversial issues associated with the introduction of GM crops, the aim of this paper is to review published data relating to the effect of introducing GM crops on the amount of pesticide used, first on a global basis and then to estimate the effect in Europe if GM crops were widely adopted.

Between 1996 and 2000, the area of genetically modified (GM) crops increased from 4 to 44 million ha (James, 2000). Soyabean, maize, cotton and oil seed rape are four of the major crops modified and herbicide tolerance (HT) and insect protection are the two main traits introduced. Glyphosate and glufosinate-ammonium are the two main herbicides for which crops have been modified for herbicide tolerance, while insect protection has been achieved through the introduction of genes encoding for truncated enterotoxins produced by strains of Bacillus thuringiensis (Bt) (Betz et al., 2000).

\section{Effect of GM crops on pesticide use}

\section{Herbicide tolerant soyabean}

Herbicide tolerant soyabean, with 26 million ha grown globally (James, 2000), is currently the dominant transgenic crop. Heimlich et al. (2000) noted that when comparing 1997 to 1998 the overall rate of herbicide use in GM soyabeans declined by nearly $10 \%$. Also, based on regression analysis, the authors estimated that 2.5 million $\mathrm{kg}$ of glyphosate replaced 3.3 million $\mathrm{kg}$ of formulated products of other synthetic herbicides such as imazethapyr, pendimethalin and trifluralin. Further work by Carpenter (2001) supported this finding.

The Dutch Centre for Agriculture and Environment (Hin et al., 2001) has probably conducted the most comprehensive review on the effect of HT soyabeans on herbicide use. The report concluded that in the USA the overall difference in pesticide use between GM and conventional soyabeans ranged from +7 to $-40 \%$ ( 1995 to 1998) with an average reduction of $10 \%$. This agrees closely with other studies. It should be noted however that the report said that the reduction might be associated with a number of other factors including soil type and climate. The report also concluded that as a result of adopting HT soyabeans, glyphosate was replacing other herbicides with less favourable environmental profiles.

Nelson et al. (2001) used data from 431 farms in 20 locations in USA to model the effect of introducing $\mathrm{H} T$ soyabeans on herbicide use. Their preliminary results indicate that, while the GM crop made the use of 16 herbicides redundant, it in- 
creased glyphosate use by 5 -fold. They also noted that glyphosate has a number of desirable characteristics when compared with other pesticides and noted that the Environmental Protection Agency (EPA) has given glyphosate its lowest toxicity rating.

While there is evidence to indicate that the introduction of HT soyabean will reduce herbicide use by up to $10 \%$ it should be noted that some authors have concluded that their use had little net effect on total herbicide used (Gianessi and Carpenter, 2000). However, even a modest reduction in pesticide use applied to 25 million ha would be highly significant in reducing overall pesticide use. If a $10 \%$ reduction in pesticide use is assumed then the use of herbicide tolerant soyabeans reduced pesticide use by 2.9 million $\mathrm{kg}$ formulated product in the year 2000 .

\section{Herbicide tolerant oil seed rape}

While the area of HT canola is small in comparison to soyabean, there are still nearly 3 million ha grown, mainly in Canada. In 2000 , over $80 \%$ of the canola growers in Western Canada adopted transgenic varieties and grew them on $55 \%$ of the 5 million ha of canola. Such a massive uptake of this technology prompted the Canola Council of Canada (2000) to commission a report on the impact of transgenic canola on growers, industry and the environment. In addition to finding that the introduction of HT canola increased yields by about $10 \%$, it was reported that transgenic crops required less herbicide than conventional crops. The total amount of herbicide used was reduced by 1.5 million $\mathrm{kg}$ in 1997 and by 6.0 million $\mathrm{kg}$ of formulated product in 2000 . Furthermore, growers planting transgenic crops used less fuel due to fewer field operations and fuel savings increased from 9.5 million litres in 1997 to 31.2 million litres of dicsel in 2000 . This saving equated to Canadian $\$ 13.1$ million, and clearly contributed to improved profitability and enhanced competitiveness of the Canadian canola growers. The decrease in diesel use would also reduce emissions of the green house gas carbon dioxide by approximately $110,000 \mathrm{t}$.

\section{Herbicide tolerant cotton}

Carpenter and Gianessi (2001) reviewed a number of crops, including HT cotton of which there were 2.1 million ha grown in 2000 (James, 2000). The authors stated that herbicide use in cotton is expected to decline with the adoption of HT cotton varieties. Application rates for conventional varieties vary from 4.9 to $8.0 \mathrm{~kg}$ formulated product/ha compared with 2.5 to $4.0 \mathrm{~kg} /$ ha for glyphosate tolerant GM varieties. Thus with 2.1 million ha grown the decrease in pesticide use associated with the introduction of HT cotton is estimated at 5.3 million $\mathrm{kg}$ formulated product in 2000. In addition, the introduction of HT varietics has been associated with a reduction in spray applications of 1.8 million ha. 


\section{Herbicide tolerant maize}

The area of HT maize grown globally is 2.1 million ha (James, 2000). Recent data collected by the consulting company Doane (2001) has shown that the use of herbicide tolerant maize has on average reduced herbicide use by $30 \%(0.69 \mathrm{~kg} / \mathrm{ha})$. This is equivalent to a reduction of 1.5 million $\mathrm{kg}$ formulated product/year.

\section{Insect protected maize}

The area of insect protected maize currently grown is 6.8 million ha (James, 2000). While the European Corn Borer (ECB) is a serious insect pest of maize grain crops causing losses ranging from 0.75 to 7.5 million t of grain/year in the USA, only $5 \%$ of the crop is sprayed against ECB due to the problems of assessing the correct time to spray. As a result the introduction of $B t$ maize has only resulted in a modest decrease in insecticide used. It is generally considered that the main reason for growing $B t$ maize is for the increased yields which occur when infestation of $\mathrm{ECB}$ is controlled by this technology. However, Munkvold and Hellmich (1999) have established that the use of $B t$ maize has the added advantage of reducing mycotoxin contamination, thus producing safer grain for both human and animals.

\section{Insect protected cotton}

In 2000 the global area of transgenic cotton was 5.3 million ha, of which 3.2 million were sown to $B t$ varieties (James, 2000). As well as being grown in the USA transgenic cotton is also grown in China, Mexico, Australia, Argentina and South Africa. Cotton is highly susceptible to a number of serious insect pests such as tobacco budworm, cotton bollworm and pink bollworm, and requires a sustained insecticide spray programme.

Gianessi and Carpenter (2001) calculated that between 1995, the year before $B t$ varieties were introduced to 1999 , the amount of insecticide used decreased by 1.2 million $\mathrm{kg}$ of formulated product, which represents $14 \%$ of all insecticides. In addition the number of spray applications/ha was reduced by 15 million which represented a 22\% reduction. The Arizona Cotton Research and Protection Council (2000) has stated that $B t$ cotton has helped to reduce insecticide use in Arizona cotton to the lowest levels in the past 20 years.

Ede et al. (2001) have just published a comprehensive review of the global, economic and social benefits of insect protected cotton. They reported that studies in the USA, Australia, China, Mexico and Spain all demonstrated an overall reduction in insecticide sprays (Addison, 1999; Novillo et al., 1999; Obando-Rodriquex et al., 1999; Xia et al., 1999). When averaged across 11 studies Ede et al. (2001) estimated that the introduction of $B t$ cotton reduced the number of sprays/ha by 
3.5 (range 1.0-7.7). When Benedict and Altman (2001) used the results from their study which reported a conservative decrease of 2.2 applications/ha this equated to a reduction in insecticide use of $2.05 \mathrm{~kg} / \mathrm{ha}$. Thus based on this figure and the fact that there were 3.2 million ha of $B t$ cotton sown in 2000 , the use of insect protected cotton reduced pesticide use by 6.6 million $\mathrm{kg}$ of formulated product in the year 2000 .

While the introduction of $B t$ cotton has markedly reduced the amount of pesticide used and the number of spray applications required/ha Gianessi and Carpenter (1999) noted that many of the traditional pesticides used in cotton production also had poor environmental characteristics.

China is a major producer of cotton and their growers are amongst the largest users of pesticides in China. Recently published data by Huang et al. (2001) examined the effect of biotechnology on pesticide use in cotton crops in China. They found that the effect of introducing $B t$ cotton on pesticide use was dramatic. In a survey conducted in 1999 and 2000 , they reported that on average growers that used $B t$ cotton reduced pesticide use from 55 to $16 \mathrm{~kg}$ formulated pro$\mathrm{duct} / \mathrm{ha}$ and the number of times the crop was sprayed from 20 to 7 . In addition to a reduction in pesticide use of $70 \%$ the authors also noted that the use of the highly toxic organochlorines and organophoshates were all but eliminated. These data also provided preliminary evidence that suggests that the use of $B t$ cotton resulted in a significant positive effect on farmers' health. They noted that $30 \%$ of farmers who used conventional cotton varieties reported health problems associated with spraying compared with only $9 \%$ who used $B t$ cotton. The authors concluded that the evidence is quite clear that $B t$ cotton reduces pesticide use and is likely to be beneficial to health and the environment.

Although India has yet to approve the commercial production of transgenic cotton, as the largest cotton producer in the world, growing 9 million ha, one might expect the use of $B t$ cotton to provide many of the same benefits as those noted in China. If $50 \%$ of the Indian cotton crop was grown as insect protected varieties the reduction in pesticide, based on the calculations earlier in this paper could amount to 9.2 million $\mathrm{kg} /$ year of formulated product.

\section{Examples of other GM crops in which pesticide use can be reduced}

The 500,000 ha of potatoes grown in the USA are currently treated with 1.2 million $\mathrm{kg}$ of pesticide. The Colorado Potato Bectle (CPB) and aphids which transmit a number of viral diseases including potato leaf roll virus (PLRV) and potato virus Y (PVY) present major problems of control for growers. In $1996 \mathrm{GM}$ potatoes which were protected against CPB were made available to growers. Initial results showed that their use decreased the number of insecticide applications from 2.78 to $1.58 /$ ha and the amount of insecticide used was reduced from 2.17 
to $1.74 \mathrm{~kg} / \mathrm{ha}$. A further development in which these potatoes were also protected against PLRV and PVY produced further reductions in insecticide use and applications required.

At a recent American Medical Association briefing Gianessi highlighted a number of food crops in which genetic modification can significantly reduce pesticide use. He quoted insect resistant sweetcorn, virus resistant citrus, virus resistant raspberries and herbicide tolerant tomatoes (American Medical Association Science News Department, 2001).

\section{AN EUROPEAN PERSPECTIVE}

Between 1990 and 1995 the annual amount of pesticide active ingredients used in the EU declined from 307,000 to $253,000 \mathrm{t}$ which represents an $18 \%$ reduction. This was due to a number of factors including lower dose rates, better application technology, changes in farm management practises, national mandatory reduction schemes, as well as payment for agri-environmental schemes. The EU 6th Environmental Action Plan has continued to focus on pesticide reduction as a priority in relation to environmental degradation. It is against this background of reducing pesticide input that the potential of GM crops to further reduce pesticide use in the EU will be estimated.

\section{Estimating the effect of introducing GM crops on pesticide use in European agriculture}

\section{Area of crops and "standard" pesticide programmes}

This section provides a preliminary assessment of the effect of introducing a range of GM crops on the amount of pesticide used and an initial assessment of its impact on energy utilization in crop production systems in the EU. Estimates will be calculated for the effect of introducing HT maize, oil seed rape and sugar beet and $B t$ cotton. In order to do so certain information is required and assumptions made. These include the area of crops grown in the EU (Table 1) and standard pesticide programmes for comparison with those used with GM varieties in selected countries (Tables 2 to 6 ).

The authors recognise the fact that a large number of pesticides have been approved for use in the conventional crops to be examined. The standard pesticide programmes utilized here were derived from discussions with agronomists and extension agents in a number of different countries. While it is outside the scope of this current paper to discuss in detail the numerous systems that have been proposed for ranking pesticides in relation to their environmental impact the 
widely used measure of their acute oral toxicity (Lethal Dose ${ }_{50}$ for rats) is included in subsequent tables.

TABLE 1

Area of some of the more important crops grown in the European Union for which there are GM crops awaiting approval for commercial cultivation

\begin{tabular}{lc}
\hline Crop & Area in $\mathrm{EU}^{\prime}\left(10^{3}\right.$ ha $)$ \\
\hline Maize & 4.403 \\
Oil seed rape & 3.041 \\
Sugar beet & 1.929 \\
Cotton & 504 \\
\hline
\end{tabular}

${ }^{1}$ source FAO statistics database. The EU represents 15 countries

Comparison between the amount of pesticide used and its innate toxicity

Maize: Table 2, presents two possible standard spray programmes for use with maize and compares them with spray programmes used for GM crops modified to be resistant to either glyphosate of glufosinate-ammonium. Whilst the first option includes atrazine, the authors are aware it has already been banned in Germany, and Holland and that legislation has recently been approved for its withdrawal from

TABLE 2

Example of a standard herbicide programmes used for maize grown in selected European countries

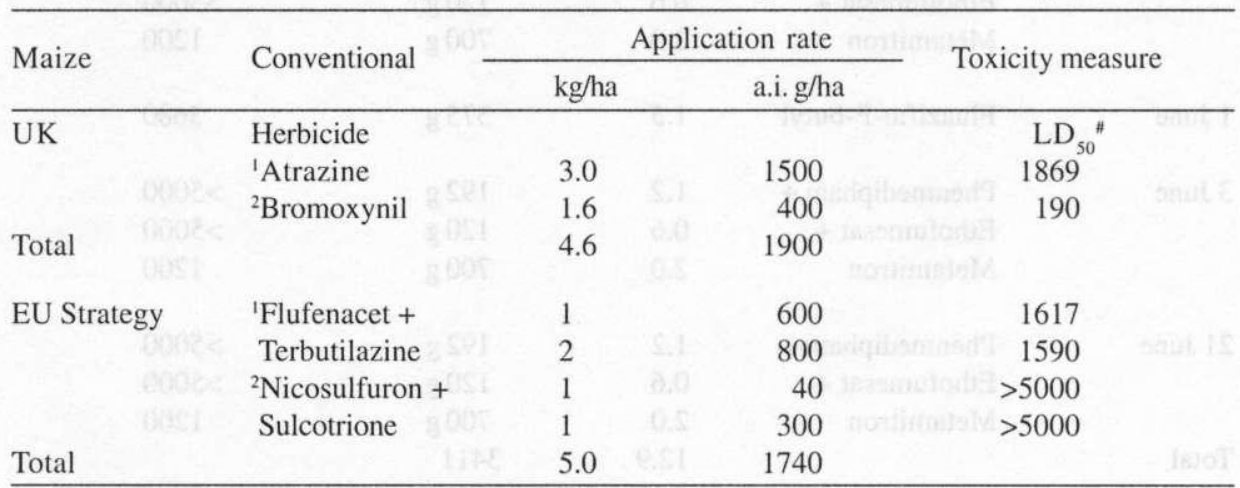

GM technology

$\begin{array}{lrrr}\text { a. }{ }^{2} \text { Glyphosate or } & 3.0 & 1080 & >5000 \\ \text { b. }{ }^{2} \text { Glufosinate } & 3.0 & 600 & 2000\end{array}$

Total

\footnotetext{
${ }^{1}$ pre-emergent spray

2 post-emergent spray

" acute oral toxicity Lethal Dose (rats) $\mathrm{mg} / \mathrm{kg}$ body weight
} 
France, but it is still widely used in the UK and the USA. The second option presents an improved pre- and post emergent spray programme.

Table 2 illustrates that the amount of pesticide $(\mathrm{kg} / \mathrm{ha})$ and a.i. $\mathrm{g} / \mathrm{ha}$ used with GM crops is substantially reduced when compared with the conventional spray programmes. Spray programmes for conventional maize crops usually require two spray applications, while with GM crops one application is usually sufficient. There is considerable concern about the persistency of atrazine in the soil, especially under conditions where soil erosion is a potential problem. The conventional EU strategy utilizes chemicals that are generally less persistent in the environment and less toxic overall than the UK strategy. The use of herbicide tolerant maize would reduce not only the number of spray applications required but also the amount of herbicide used both as $\mathrm{kg} / \mathrm{ha}$ and a.i. $\mathrm{g} / \mathrm{ha}$.

Sugar beet: Sugar beet is planted at a relatively wide row spacing and is slow to reach full ground cover, which provides the opportunity for a broad spectrum of weeds to establish. This explains the range and frequency of herbicide use outlined in Table 3.

TABLE 3

Example of a standard herbicide programmes used for sugar/fodder beet in Denmark'

\begin{tabular}{|c|c|c|c|c|}
\hline \multirow{2}{*}{ Sugar bect } & \multirow{2}{*}{ Conventional } & \multicolumn{2}{|c|}{ Application rate } & \multirow{2}{*}{ Toxicity measure } \\
\hline & & $\mathrm{kg} / \mathrm{hat}$ & a.i.g/ha & \\
\hline Denmark & Herbicide & & & $\mathrm{LD}_{50}{ }^{*}$ \\
\hline \multirow[t]{3}{*}{16 May } & Phenmedipham + & 1.2 & $192 \mathrm{~g}$ & $>5000$ \\
\hline & Ethofumesat + & 0.6 & $120 \mathrm{~g}$ & $>5000$ \\
\hline & Metamitron & 2.0 & $700 \mathrm{~g}$ & 1200 \\
\hline 1 June & Fluazilio-P-butyl & 1.5 & $375 \mathrm{~g}$ & 3680 \\
\hline \multirow[t]{3}{*}{3 June } & Phenmedipham + & 1.2 & $192 \mathrm{~g}$ & $>5000$ \\
\hline & Ethofumesat + & 0.6 & $120 \mathrm{~g}$ & $>5000$ \\
\hline & Metamitron & 2.0 & $700 \mathrm{~g}$ & 1200 \\
\hline \multirow[t]{3}{*}{21 June } & Phenmedipham + & 1.2 & $192 \mathrm{~g}$ & $>5000$ \\
\hline & Ethofumesat + & 0.6 & $120 \mathrm{~g}$ & $>5000$ \\
\hline & Metamitron & 2.0 & $700 \mathrm{~g}$ & 1200 \\
\hline \multirow[t]{2}{*}{ Total } & & 12.9 & 3411 & \\
\hline & GM Technology & & & \\
\hline 1 June & Glyphosate & 3.0 & $\operatorname{los} \mathrm{g}$ & $>5000$ \\
\hline 29 June & Glyphosate & 3.0 & $1080 \mathrm{~g}$ & $>5000$ \\
\hline Total & & 6.0 & 2160 & \\
\hline
\end{tabular}

${ }^{1}$ Ministry of Environment and Energy, National Envirommental Research Institute (2001)

" acute oral toxicity Lethal Dose (rats) $\mathrm{mg} / \mathrm{kg}$ body weight 
Table 3 uses information from the Ministry of Environment and Energy (2001) in Denmark. It shows that the use of herbicide tolerant (glyphosate) sugar beet reduced the amount of pesticide used from 12.9 to $6.0 \mathrm{~kg} / \mathrm{ha}$ a reduction of $53 \%$ while the active ingredient declined from 3411 to $2160 \mathrm{~g} / \mathrm{ha}$, which is equivalent to a $37 \%$ reduction. In addition the number of spray applications decreased from four to two. One of the chemicals used in the conventional programme (ethofumesate) is very persistent in normal ficld conditions.

Winter oil seed rape: Oil seed rape is traditionally regarded as a combinable breakcrop in the EU. It can establish very rapidly in favourable conditions and once established out-competes many weeds. Herbicides are often used early in the establishment phase to control volunteer cereals but subsequent control of broadleaved weeds is often necessary. Table 4 indicates that the introduction of herbicide tolerant oil seed rape may decrease the application rate of herbicide from 4.0 to $3.0 \mathrm{~kg} / \mathrm{ha}$, a reduction of $25 \%$, while the amount of active ingredient applied/ha will decrease from $1700 \mathrm{~g} / \mathrm{ha}$ to $600 \mathrm{~g} / \mathrm{ha}$ a reduction of $65 \%$. In addition it should be noted that the number of sprays applications would also be reduced from 3 to 1 . Under most conditions the field breakdown of all chemicals in Table 4 is relatively rapid.

Cotton: The standard spray programme and that required for Bt cotton presented in Table 5, was reported from studies conducted in Spain. The results show that the introduction of $B t$ cotton reduced the amount of pesticide used/ha by $60 \%(20.3$ compared with $8.1 \mathrm{~kg} / \mathrm{ha}$ ) and active ingredient by nearly $40 \%$ (2285 compared with $1410 \mathrm{~g} / \mathrm{ha}$ ). In addition the number of spray applications decreased from four to three. This decrease is less than the average reduction of two spays noted in the recent review published by Ede et al. (2001).

TABLE 4

Example of a standard herbicide programmes used for winter oil seed rape in the UK

\begin{tabular}{|c|c|c|c|c|}
\hline \multirow{2}{*}{ Winter rape } & \multirow{2}{*}{ Conventional } & \multicolumn{2}{|c|}{ Application rate } & \multirow{2}{*}{ Toxicity measure } \\
\hline & & $\mathrm{kg} / \mathrm{ha}$ & a.i.g/ha & \\
\hline \multirow[t]{6}{*}{ UK } & Herbicide & & & $\mathrm{LD}_{50}{ }^{\prime}$ \\
\hline & 1. Kataraman & 2.0 & & \\
\hline & Quinmeric & & 250 & $>5000$ \\
\hline & Melazachlor & & 750 & 2780 \\
\hline & 2. Laser & 1.0 & 200 & $>5000$ \\
\hline & 3. Kerb & 1.0 & 500 & $>5000$ \\
\hline \multirow[t]{2}{*}{ Total } & & 4.0 & 1700 & \\
\hline & $\begin{array}{l}\text { GM Technology } \\
\text { Glufosinate }\end{array}$ & 3.0 & 600 & 2000 \\
\hline Total & & 3.0 & 600 & \\
\hline
\end{tabular}

' acute oral toxicity Lethal Dose (rats) $\mathrm{mg} / \mathrm{kg}$ body weight 
TABLE 5

Example of standard pesticide programme used for conventional and insect protected $(B t)$ cotton grown in Spain

\begin{tabular}{|c|c|c|c|c|}
\hline \multirow{2}{*}{ Cotton } & \multirow{2}{*}{$\begin{array}{c}\text { Conventional/GM } \\
\text { Technology }\end{array}$} & \multicolumn{2}{|c|}{ Application ratc } & \multirow{2}{*}{ Toxicity measure } \\
\hline & & l/ha & a.i. g/ha & \\
\hline Spain & Insecticide & & & $\mathrm{LD}_{50 t}{ }^{\prime \prime}$ \\
\hline \multirow[t]{2}{*}{22 June } & Methomyl $(12 \%)+$ & 1.5 & 180 & $34^{3 t}$ \\
\hline & Endosulfan (36\%) & 3.5 & 245 & 70 \\
\hline \multirow[t]{2}{*}{27 June } & Endosulfan $(35 \%)+$ & 3.5 & 245 & 70 \\
\hline & Methomyl $(20 \%)$ & 0.7 & 140 & 34 \\
\hline \multirow[t]{2}{*}{$12 \mathrm{July}$} & 'Endosulfan $(35 \%)+$ & 3.5 & 245 & 70 \\
\hline & 'Methomyl (20\%) & 0.7 & 140 & 34 \\
\hline \multirow[t]{2}{*}{3 August } & Endosulfan $(35 \%)+$ & 4.0 & 245 & 70 \\
\hline & Methomyl $(20 \%)$ & 1.5 & 300 & 34 \\
\hline \multirow[t]{2}{*}{17 August } & 'Endosulfan $(35 \%)+$ & 4.0 & 245 & 70 \\
\hline & Methomyl (20\%) & 1.5 & 300 & 34 \\
\hline \multicolumn{5}{|l|}{ Total } \\
\hline \multicolumn{2}{|c|}{ Conventionat } & 20.27 & 2285 & \\
\hline \multicolumn{2}{|c|}{ GM Technology } & 8.07 & 1410 & \\
\hline
\end{tabular}

' sprays nol required for GM cotton

\# acute oral toxicity Lethal Dose (rats) $\mathrm{mg} / \mathrm{kg}$ body weight

Potential effect of the introduction for commercial planting of GM crops on levels of pesticides used and their impact on energy use in the EU

The estimates presented in Table 6 indicate that if $50 \%$ of the maize, oil seed rape, sugar beet, and cotton was grown in the EU as HT or $B t$ varieties the amount of pesticide used would fall by 14.5 million $\mathrm{kg}$ formulated product/annum which represents a decrease of 4.4 million $\mathrm{kg}$ of active ingredient. In addition there would be a reduction of 7.5 million ha sprayed.

\section{DISCUSSION AND CONCLUSIONS}

The authors recognize that the debate surrounding genetic modification is both complex and that it is a technology to which many individuals and organizations are opposed. In this paper we have considered just one important aspect of the environmental debate surrounding the introduction of GM crops and that is their poten- 
TABLE 6

Potential reduction in pesticide use in the EU if $50 \%$ of maize, oil seed rape, sugar beet and cotton are grown as $\mathrm{GM}$ varieties and the reduction in number of spray applications resulting from the introduction of GM technology

\begin{tabular}{|c|c|c|c|c|c|c|c|}
\hline \multirow[b]{2}{*}{ Crop } & \multirow{2}{*}{$\begin{array}{c}\text { Area of GM } \\
\text { crop } \\
\text { millions ha }\end{array}$} & \multicolumn{4}{|c|}{ Pesticide reduction } & \multicolumn{2}{|c|}{$\begin{array}{c}\text { Reduction in spray } \\
\text { application }\end{array}$} \\
\hline & & $\begin{array}{l}\text { Per ha } \\
\text { kg }\end{array}$ & $\begin{array}{c}\mathrm{EU} \\
\text { millions } \\
\mathrm{kg}\end{array}$ & $\begin{array}{c}\text { Per ha } \\
\text { a.i. kg/ha }\end{array}$ & $\begin{array}{c}\text { EU } \\
\text { millions } \\
\text { kga.i. }\end{array}$ & $\begin{array}{c}\text { Per ha } \\
\text { Nos. } \\
\text { of sprays }\end{array}$ & $\begin{array}{c}\text { EU } \\
\text { millions } \\
\text { ha }\end{array}$ \\
\hline Maize & 2.2 & 1.6 & 3.52 & 0.820 & 1.80 & 1 & 2.2 \\
\hline Oil seed rape & 1.5 & 1.0 & 1.0 & 1.10 & 1.10 & 2 & 3.0 \\
\hline Sugar beet & 1.0 & 6.9 & 6.9 & 1.251 & 1.25 & 2 & 2.0 \\
\hline Cotton & 0.25 & 12.2 & 3.05 & 0.838 & 0.21 & 1 & 0.25 \\
\hline Total & 4.95 & & 14.47 & & 4.36 & & 7.45 \\
\hline
\end{tabular}

1 UK option presented in Table 2

EU - European Union

tial effect on pesticide use if grown widely in the EU. However, it should be noted that further studies are required to examine in detail a number of other important environmental issues.

In countries where GM crops are at present widely grown, published data presented in this paper shows that the adoption of GM technology can lead to a marked reduction in pesticide use. However, the size of the reduction varies between crops and the introduced trait. For example only a modest reduction in pesticide use of $10 \%$ is associated with the introduction HT soyabeans but a large and highly significant reduction of $60 \%$ in pesticide use is recorded for $B t$ varieties of cotton. Although the total reduction in pesticide use of 2.9 million $\mathrm{kg}$ associated with HT soyabeans is important the most valuable contribution to environmental benefits of GM soyabeans may be that they encourage farmers to use conservation tillage techniques. While detailed consideration of this topic is beyond the scope of this paper further work is needed to quantify the environmental benefits associated with conservation tillage.

It is estimated that the use of HT soyabean, oil seed rape, cotton and maize varieties reduced pesticide use by a total of 22.3 million $\mathrm{kg}$ of formulated product in the year 2000. It is important that further studies are conducted to quantify the benefits to the environment that can occur from such a large reduction in pesticide use.

Further data have been presented for the likely impact in terms of pesticide use if GM crops were introduced into the EU. The estimate indicates that if $50 \%$ of the maize, oil seed rape, sugar beet, and cotton was grown as herbicide tolerant or insect protected GM varieties the amount of pesticide used in the EU/annum would 
fall by 14.5 million $\mathrm{kg}$ of formulated product. In addition, the amount of a.i. applied would decrease by 4.4 million $\mathrm{kg}$ and there would be a reduction of 7.5 million ha sprayed, which would save 20.5 million litres of diesel and result in a reduction of approximately 73,000 t of carbon dioxide being released into the atmosphere (Taylor et al., 1995). These values could increase markedly as countries such as Turkey growing 700,000 ha of cotton enter the EU.

Despite the limitations in the analysis presented in this paper and the overall complexities of the debate the authors believe that GM technology has the potential to markedly reduce overall pesticide use. Further, if less chemical is used and the number of spray applications are reduced there will be a considerable saving in support energy required for crop production. While large-scale commercial plantings of GM crops have not yet occurred in the EU, based on the data presented in Table 6 , a $50 \%$ planting of maize, oil seed rape, sugar beet and cotton to GM varieties could result in the saving of $7.60 \times 10^{11} \mathrm{GJ}$ of energy per year or the equivalent of 20.5 million litres of diesel fuel. These calculations assume an energy cost of $115 \mathrm{MJ} /$ ha for spray application and an energy value of diesel of $37 \mathrm{MJ} / \mathrm{l}$ (Bailey and Basford, 1998). Further detailed work is required to determine the total reduction in energy input resulting from the introduction of GM technology. These more complex calculations would need to include not only the different encrgy costs of pesticide productions but also the fact that the use of less pesticide will require less raw ingredients and inerts, less diesel fuel in the manufacturing process, less fuel for shipment and storage, less water and fuel used in spraying, and of course, less packaging for their containment and distribution to and within the agricultural sector. Further research is also required to investigate and estimate the impacts of the use of GM's on the frequency and severity of pollution incidents relating to pesticides and water courses.

Looking to the future, a recent study by Kline and Company, a New Jersey based consulting firm, analysed the future trends in pesticide use in the USA by the year 2009. Their analyses of the market indicated that by 2009 , HT and insect protected crops would contribute to an annual reduction of 20 million and 6 million $\mathrm{kg}$ of herbicide and insecticide active ingredient respectively. Ariel et al. (2001) have also estimated that the development of GM potatoes resistant to late blight could reduce pesticide use by 41 million $\mathrm{kg}$ of active ingredient. The recent news from AgCanada that its scientists have just found the gene in wild Mexican potatoes for resistance to late blight suggests that this is a reality (AgraFood Biotech, 2001). The authors feel that if the reductions indicated in the current paper and those envisaged could be achieved then there should be a flow of positive environmental benefits to society at large.

Whilst it is important that the rigorous investigation of the impact of the introduction of GM crops in the EU continues, it is surprising that some of the positive aspects of their introduction appear to be ignored. For instance we would agree 
with Carpenter (2001) who suggests that whilst scientists continue to debate risks, such as the the effects of genetically engineeed maize pollen on butterfly populations, dramatic reductions in pesticide use achieved through the introduction of GM crops remain largely ignored. This potential for reduction in pesticide use is reflected in the figures of companies such as BASF who have stated that, since the introduction of GM crops, their sales have declined by US $\$ 300$ million/annum (Manitoba Co-operator, 1999).

While it is beyond the scope of this paper to review in detail the extensive literature on the public perception of GM technology, it should be noted that in a recent survey conducted in the USA about $75 \%$ of people asked, said they approved of the use of biotechnology to produce insect protected crops which reduce the use of pesticides. This is supported by work carried out in Canada at the University of Guelph. The public was offered the choice of either buying conventional or GM sweetcorn and potatoes. A list of the sprays used on the produce was clearly visible for the public to see. Under these circumstances $60 \%$ of the public selected to buy GM rather than conventional produce (http:/www.plant.uoguelph.ca/ safefood). It is interesting to speculate how consumers in Europe would react if given the same choice and information that was provided to the Canadian shoppers.

\section{REFERENCES}

Addison S., 1999. Ingard Cotton: Research and Performance Review 1998-1999. Monsanto Australia Ltd. Melbourne VIC (Australia)

AgraFood Biotech, 2001. Two for one resistance in potatoes. AgraEurope, London

American Medical Association, 2001. New study shows that biotechnology offers significant benefits to diverse crops. News Letter, October 2001, Washington, DC

Antilla L., 2000. Study shows no increase in pest resistance to genetically modified cotton. Arizona Cotton Research and Protection Council. News Release, November 2000, Tucson

Araji A.A., Guenthner J.F., 2001. The economic and environmental impacts of investments in the devclopment and adoption of genetically modified potato. Proceedings of $5^{\text {th }}$ International Consortium on Agriculture, Biotechnology Research. Ravello (ltaly), pp. 179-180 (Abstr.)

Bailey A., Basford W.D., 1998. Energy use in UK integrated arable farming systems. Paper presented at The Rank Prize Funds. Mini-Symposium on Energy in Agriculture. Grasmere, Cumbria

Benedict J.H., Altman D.W., 2001. Commercialisation of transgenic cotton expressing insecticidal crystal protein. In: J.J. Jcnkins, S. Saha (Editors). Genetic Improvement of Cotton: Emerging Technologies. Science Publ., Enfield, NH, pp.137-201

Betz F.S., Hammond B.G., Fuchs R.L., 2000. Safety and advantages of Bacillus thuringiensis-protected plants to control insect pests. Toxicol. Pharmacol. 32, 156-173

Borlaug N., Dowsewell C., 2001. The unfinished Green Revolution - the future role of science and technology in feeding the developed world. Paper presented at the Seeds of Opportunity Conference, June 2001, London 
Canola Council of Canada, 2001. Impact of Transgenic Canola on Growers, Industry and Environment. http://www.canola-council.org

Carpenter J.E., 2001. Case Studies in Benefits and Risks of Agricultural Biotechnology: Roundup Ready Soybeans and B1 Field Corn. National Centre for Food and Agricultural Policy, Washington, DC

Carpenter J.E., Gianessi L.P., 2001. Agricultural Biotechnology: Updated Benefil Estimates. National Centre for Food and Agricultural Policy, Washington, DC

Carson R., 1963. Silent Spring. Hamish Hamilion, London

Danish Ministry of Environment and Energy, National Environmental Research Institute, 2001. Flora and Fauna in Roundup Tolerant Fodder Beet Ficlds. Technical Report No. 349, Roskilde

Doane, 2001. Doane Agricultural Report. Doane, St Louis

Edge J.M., Benedict J.H., Carroll J.P., Reding H.K., 2001. Bollgard cotton: an assessment of global, economic, environmental and social benefits. J. Cotton Sci. 5, 1-8

Environmental Protection Agency, 1989. Carbofuran: A Special Review Technical Support Document. US Environmental Agency, Office of Pesticides and Toxic Substances, Washington, DC

Farah J., 1994. Pesticide policies in developing countries: do they encourage excessive use. World Bank Discussion, Paper Number 238. Washington, DC

Giannessi L.P., Carpenter J.E., 2000. Agricultural biotechnology: Benefits of transgenic soybeans. National Center for Food and Agricultural Policy, Washington, DC

Giannessi L.P., Silvers C.S., 2000. Trends in crop pesticide use: comparing 1992 and 1997. National Center for Food and Agricultural Policy, Washington, DC

Heimlich R.E., Fernandez-Cornejo J., McBride W., Klotz-Ingram C., Jans S., Brooks N., 2000. Genetically engineered crops: has adoption reduced pesticide use? Agricultural Outlook 2000. USDA Economic Research Service, Washington, DC

Hin C.J.A., Schenkelaars P., Pak G.A., 2001. Agronomic and environmental impacts of commercial cultivation of glyphosate tolerant soybean in the USA. Dutch Centre for Agriculture and Environment, Utrecht (The Netherlands)

Huang J., Hu R., Pray C., Quiao F., Rozelle S., 2001. Biotechnology as an alternative to chemical pesticides: A case study of $\mathrm{Bt}$ cotton in China. Proceedings of $5^{\text {th }}$ International Consortium Agriculture, Biotechnology Research. Ravello (Italy), pp. 109-110 (Abstr.)

James C., 2000. Global review of commercialised transgenic crops. Publ. International Service for the Acquisition of Agri-biotech Applications. Ithaca, NY

Krebs J.R, Wilson J.D., Bradbury R.B.. Sirwardena G.M., 1999. The second silent spring. Nature, $400,611-612$

Manitoba Co-operator, 1999. Biotechnology Cuts into Profit Margins. Manitoba Co-operator, 14 p. 1. Winnipeg

Munk vold G.P., Hellmich R.L., 1999. Comparison of fumonisin concentrations in kernels of transgenic Bt maize hybrids and non transgenic hybrids. Plant Dis. 83, 130-138

Nelson G.C., Bullock D., Nitsi E., 2001. Environmental effects of GMO's: Evidence from the use of glyphosatc-resistant soybeans. Procecdings of $5^{\text {th }}$ International Consortium on Agriculture, Biotechnology Research. Ravello (lialy), pp. 125-126 (Abstr)

Novillo C., Soto J., Costa J., 1999. Results of genetic protection of the cotton plant against the larvae in Spain (in Spanish). Bol. San. Veg. Plagas 25, 383-393

Obando-Rodriquex A.J., Garcia J.G., Garcia J.M.O., Magana J.E.M., Garcia A.M., 1999. Bolligard gen. Cotton as an altemative for IPM in Delicias, Chihuahua, Mexico. In: Proceedings of Beltwide Cotton Conference. Orlando, FL. National Cotton Council Amer, Memphis, TN, pp. 967-968 (Abstr.) 
Oerke E.C., Dehne H.W., Scolenbeck F., Weber A., 1995. Crop Production and Crop Protection: Estimated Losses in Major Food and Cash Crops. Elsevier, Amsterdam

Paoletli M.G., Pimentel D.S., 2000. Environmental risks of pesticides versus genetic engineering for agricultural pest control. J. Agr. Environ. Ethic 12, 279-303

Pesticide Manual: a World Compendium, 2000. C.D.S. Tomlin (Editor). $12^{\text {th }}$ Edition. Farnham: British Crop Protection Council

Phipps R.H., Becver D.E., 2000. New technology: Issues relating to the use of genetically modified crops. J. Anim. Feed Sci. 9, 543-561

Repetto R., Baliga S., 1996. Pesticides and the Immune System: The Public Health Risks. World Resources Institute. Washington, DC

Rola A.C., Pingali P.L., 1993. Pesticides, rice productivity and farmers health: an economic assessment. Internationa! Rice Research Institute and World Resources Institute. Los Banos, Philippines and Washington, DC

Rother H.A., 1998. Influence of pesticide risk perception on the health of rural South African, women and children. International Conference on Pesticide Use in Developing Countries - Impact on Health and Environment. San Jose (Costa Rical). Afr. News Letl. 2, 1-10.

Riebe J.F., Zalewski J.C.. 2001. Pesticjde reduction and disease control with genetically modified potato. Environ. Biosafety Res. (in press)

Taylor A.E.B., O'Callaghan P.W., Probert S.D., 1995. Energy audit of an English farm. Appl. Energ. $44,315-335$

Tillman D., 1999. Global environmental impacts of agricultural expansion: the need for sustainable and efficient practices. Proc. Nat. Acad. Sci. USA 96, 5995-6000

Yudelman M., Ratta A., Nygaard D., 1998. Pest Management and Food Production: Looking to the Future. International Food Policy Research Institute, Food Agriculture and the Environment Discussion, Paper 25. Washinglon, DC

Xia J.Y., Cui J.J., Ma L.H., Dong S.X., Cui S.X., 1999. The role of transgenic Bt cotton in integrated pest management. Acta Gossypii Sinica 11, 57-64

\section{STRESZCZENIE}

Korzystny wplyw uprawy roślin genetycznie zmodyfikowanych na środowisko: perspektywy i możliwości ograniczenia stosowania pestycydów w skali światowej i europejskiej

Uważa się, że Zielona Rewolucja, która spowodowała poprawę odmian, zwiększenie nawadniania, zużycia nawozów sztucznych i pestycydów, zwiększyła możliwość wyżywienia ludności globu, liczącej obecnie 6 bilionów. W opracowaniu uznaje sį̣ wprawdzie znaczenie pestycydów dla z.mnicjszenia strat $w$ produkeji roślinnej, jednakże zwraca się także uwagę na ich potencjalny ujemny wpływ na zdrowie ludzi, zwłaszcza w krajach rozwijającyclı się, oraz na środowisko. Odpowicdzią przemyshu rolnego jest zastosowanic nowych technologii, jak zmnicjszenie dawek stosowania pestycydów o ściśle określonym działaniu, o mniejszej toksyczności i zmnicjszonej trwałości. Jednakże, wraz ze wzrastającą światową populacją ludności, obniżnia tempa wzrostu plonów w wyniku hodowli konwencjonalnej oraz zmniejszenia obszarów ziemi przeznaczonych do produkcji żywności, istnieje potrzeba wprowadzenia nowych technologii celem produkcji większej ilości żywności o wyższej wartości odżywczej, technologii zrównoważonych i przyjaznych środowisku. Autorzy przyznaja, że wprowadzenie roślin uprawnych zmodyfikowanych genetycznic (GM) jest wpraw- 
dzie kontrowersyjne, jednakże korzyści z ich uprawy, łącznie z ich wpływem na stosowanie pestycydów, zaczyna się wykazywać. Publikowane dane wykorzysluje się do określenia wpływu uprawy roślin GM na stosowanie peslycydów w skali światowej, a następnie do szacowania wplywu jaki może mieć ich szeroka uprawa w krajach Unii Europejskicj. W skali światowej uprawa GM ograniczyla stosowanic pestycydów, przy czym stopień obniżenia różni się w zależności od rośliny i wprowadzanej cechy.

Oszacowano, że wprowadzenie do uprawy soi, rzepaku, bawełny oraz kukurydzy zmodyfikowanych genetycznie w kierunku tolerancji na herbicydy oraz GM odmian bawełny odpomej na owady zmnicjszylo w $2000 \mathrm{r}$ zużycic pestycydów w skali światowcj o 22,3 miliona kg preparatów. Z przeprowadzonych szacunków wynika, że gdyby 50\% kukurydzy, rzepaku, buraków cukrowych i bawełny uprawianych w UE stanowiły odmiany GM, wówczas roczne zużycic pestycydów w Unii Europejskiej obniżyłoby się o 14,5 miliona kg preparatów (4,4 miliona kg aktywnego składnika). Ponadto można by zmniejszyć o 7,5 miliona ha powierzchnię opryskiwaną, co zaoszczędziłoby 20,5 miliona litrów olcju napędowego, a w następstwic tego zmnicjszyłoby o około 73,000 t ilość dwutlenku węg!a wydzielanego do atmosfery. W opracowaniu tym także wskazano na obszary, w których modyfikacja genetyczna mogłaby dodatkowo znacznie ograniczyć stosowanic pestycydów w skali światowej. 